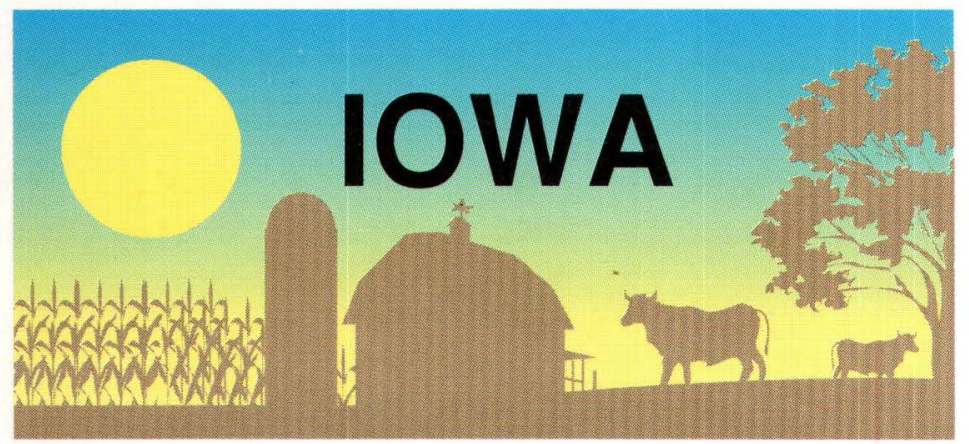

\author{
U.S. Department of the Intenor \\ U.S. Geological Survey
}

\title{
Urban Stormwater Runoff Study at Davenport, lowa
}

\section{Introduction}

Urban stormwater runoff is being investigated as a nonpoint source of pollution across the country as urban areas with populations over 100,000 conduct studies designed to meet U.S. Environmental Protection Agency guidelines for National Pollutant Discharge Elimination System permits for their stormwater discharges. From 1991 through 1994, the City of Davenport, Iowa (fig. 1), and the U.S. Geological Survey cooperatively conducted a study designed to meet technical conditions of the permit application and to develop the criteria for ongoing monitoring during the term of the permit.

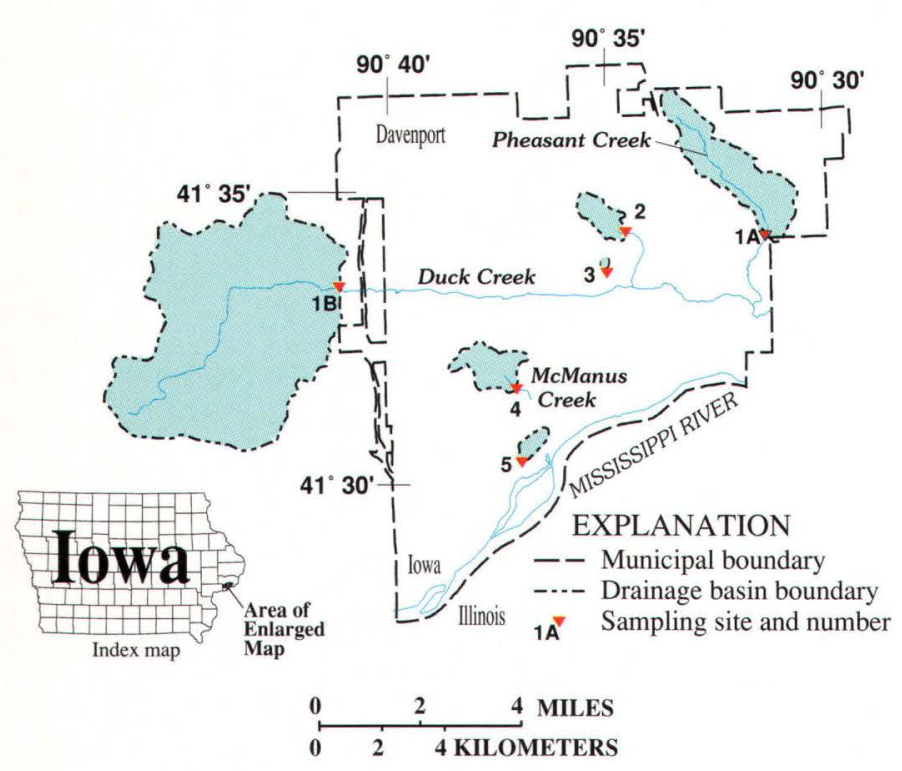

Figure 1. Stormwater runoff sampling sites and their drainage basins.

\section{Site selection and land use}

The six open-channel sampling sites shown in figure 1 were selected to characterize the water quality of storm runoff from the following five land-use types: (1A, 1B) agricultural and vacant, (2) residential, (3) commercial, (4) parks and wooded areas, and (5) industrial. The sites were selected on the basis of uniformity of land use in the drainage basin, hydraulic factors allowing an adequate stage-discharge rating to be established, maximization of catchment size while maintaining reasonable uniformity of land use, accessibility, and the safety of those collecting the samples. A geographic information system was used to catalog landuse areas for Davenport and within the area drained by the storm-sewer network (fig. 2) and to assist in identification of representative sampling sites.

\section{Data collection and processing}

At each of the sampling sites, data loggers recorded water-level and rainfall information. Water levels were measured in a stilling well connected to the channel, and rainfall was measured in 0.01-inch increments by a tipping-bucket rain gage. Manual discharge measurements taken periodically during and between storm events were used to develop a stage-discharge relation for each site. This information allowed flow to be determined for specified stream stages. Most samples were collected manually, but automatic samplers collected three 2.8-liter discrete samples at 15-minute intervals when personnel could not be at the sites when stormwater runoff began. Figure 3 shows sampling site 2 with a rain gage and solar panel on a tower to prevent interference from nearby trees and a shelter for the water-level sensor, the data logger, and the automatic sampler.

Three complete sets of stormwater runoff samples were collected for each of the five land-use types. Stormwater samples for a particular site were collected 30 or more

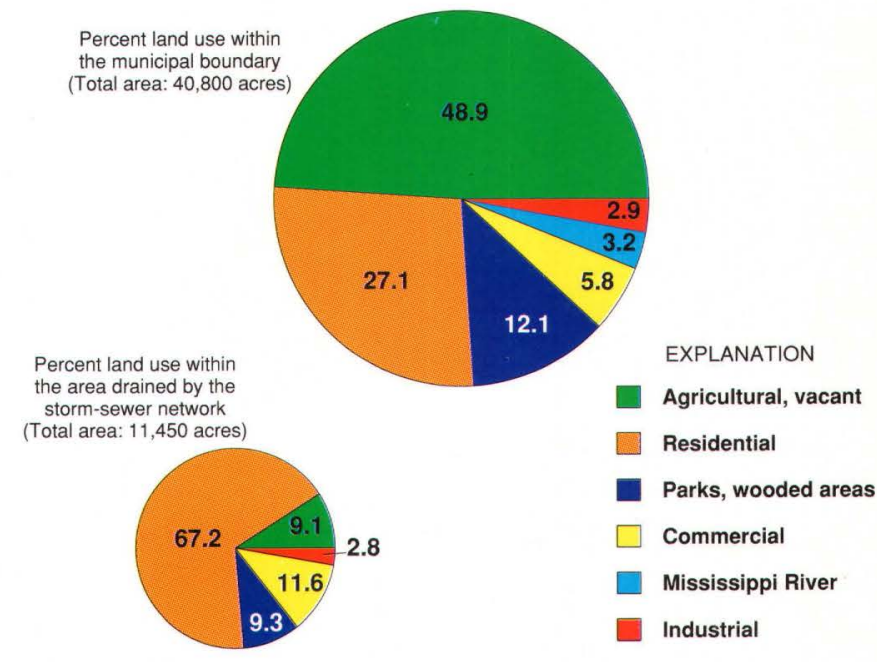

Figure 2. Percent land use within the municipal boundary and within the area drained by the Davenport municipal storm-sewer network. [Based on information from the City of Davenpor (Kenneth Oestreich, Davenport Department of Community and Economic Development,
written commun., 1991) and the Bi-State Metropolitan Planning Commission (1984)]. 
days apart and after about a 72-hour period of less than 0.1 inch of rain had elapsed. Each set of samples consisted of both grab and flow-weighted composite samples (fig. 4). Grab samples were collected manually within the first hour of the runoff event. Flow-weighted composites were produced by combining flow-weighted volumes of discrete samples collected about every 15 minutes for the first 3 hours of the event or until discharge returned to pre-event levels, whichever came first.

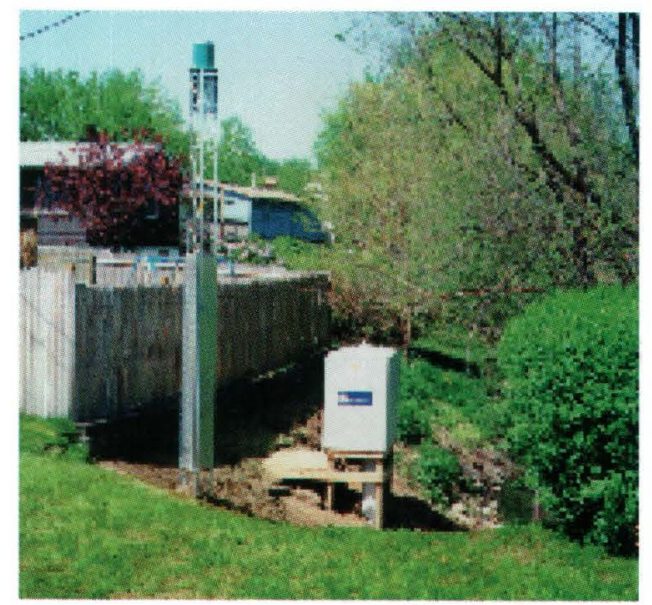

Figure 3. Rain gage and instrument shelter at sampling site 2 (residential).
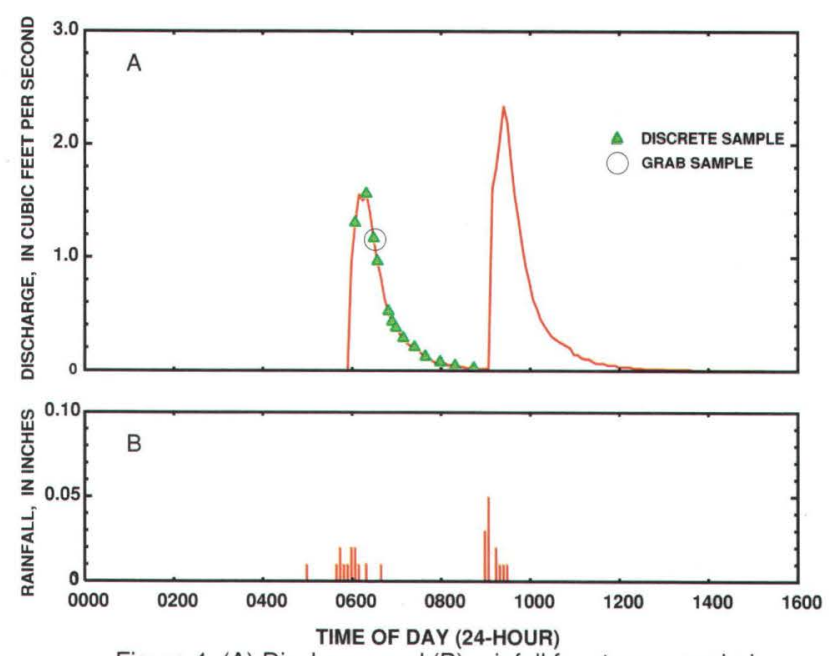

Figure 4. (A) Discharge and (B) rainfall for storm sampled on October 8,1992 , at sampling site 3 (commercial).

\section{Data analysis}

Grab samples were analyzed for $\mathrm{pH}$, temperature, cyanide, oil and grease, total phenols, volatile organic carbons, and bacteria. Water-quality results of the flow-weighted composites, in conjunction with detailed rainfall and landuse information, were used to estimate annual loads of 12 constituents for the area drained by the Davenport stormsewer network. Annual loads were estimated for chemical oxygen demand, biochemical oxygen demand, suspended solids, dissolved solids, ammonia plus organic nitrogen, total nitrogen, dissolved phosphorus, total phosphorus, cadmium, copper, lead, and zinc. In addition, the composite samples were tested for many other inorganic and organic parameters, including total organic carbon, major ions, metals, acid/base-neutral organics, organochlorine pesticides, and polyaromatic hydrocarbons, in an effort to detect unusual or potentially hazardous conditions.

-Bryan D. Schaap

\section{Additional reading}

Bi-State Metropolitan Planning Commission, 1984, Map of existing land use-1984 in the Quad City metropolitan area: scale approximately 1:75,000.

Driver, N.E., and Tasker, G.D., 1990, Techniques for estimation of storm-runoff loads, volumes, and selected constituent concentrations in urban watersheds in the United States: U.S. Geological Survey Water-Supply Paper 2363, 44 p.

Schaap, B.D., and Lucey, K.J., 1994, Selected nutrients in stormwater runoff from Davenport, Iowa, 1992: U.S. Geological Survey Water-Resources Investigations Report 94-4130, 29 p.

U.S. Environmental Protection Agency, 1992a, Guidance manual for the preparation of part 1 of the NPDES permit applications for discharges from municipal separate storm sewer systems: EPA Report 505/8-91$003 \mathrm{~A}$, various pagination.

1992b, Guidance manual for the preparation of part 2 of the NPDES permit applications for discharges from municipal separate storm sewer systems: EPA Report 833-B-92-002, various pagination.

For more information, please contact:

District Chief

U.S. Geological Survey

P.O. Box 1230

Federal Building, Room 269

400 South Clinton Street

Iowa City, Iowa 52244

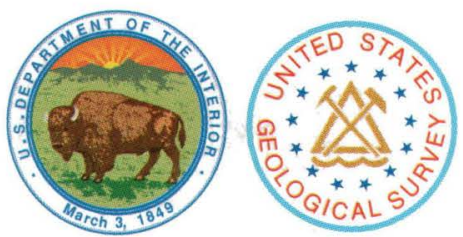

FS-177-95 